\title{
Mucosa-associated cultivable aerobic gut bacterial microbiota among colorectal cancer patients attending at the referral hospitals of Amhara Regional State, Ethiopia
}

Yesuf Adem Siraj ${ }^{1,4^{*}}$ D, Melesse Gebeyehu Biadgelign ${ }^{2}$, Mensur Osman Yassin $^{3}$ and Yohannes Zenebe Chekol ${ }^{1,5}$

\begin{abstract}
Background: Colorectal cancer (CRC) is one of the top ten causes of cancer deaths in the world. Despite an increased prevalence of colorectal cancer has been documented from developing countries, there is no any report regarding gut microbiota among colorectal cancer patients in Ethiopia. Therefore, the current study evaluated cultivable aerobic gut bacterial distributions among malignant and its adjacent normal biopsies of CRC patients.

Methods: CRC patients who were under colorectal cancer resection surgery during April 2017 to February 2018 at Felege Hiwot Referral and University of Gondar Teaching Hospitals enrolled in the study. Biopsy specimens were taken from malignant and its adjacent normal-appearing tissues. Bacterial cultivation, quantification and characterization of saline washed biopsies were performed under aerobic and candle jar conditions. Differences in bacterial microbiota compositions between malignant and normal tissue biopsies were evaluated and analyzed using Microsoft excel 2010 and GraphPad Prism5 statistical software.

Results: Fifteen CRC patients were participated with a mean age of $53.8 \pm 10.8$ years old and majorities (73.3\%) of patients were in between the age groups of 40 and 60 years old. The mean \pm SD bacterial microbiota of malignant biopsies $\left(3.2 \times 10^{5} \pm 1.6 \times 10^{5} \mathrm{CFU} / \mathrm{ml}\right)$ was significantly fewer than that of adjacent normal tissue biopsies $\left(4.0 \times 10^{5} \pm 2.2 \times 10^{5} \mathrm{CFU} / \mathrm{ml}\right)$. This dysbacteriosis is positively correlated with the occurrence of CRC $(p=0.019)$. Proteobacteria (55.6\%), Firmicutes (33.3\%) and Fusobacteria (11.1\%) were the most frequently isolated phyla from non-malignant biopsies while only Proteobacteria (58.8\%) and Firmicutes (41.2\%) were from malignant ones. Family level differences were observed among phyla (Firmicutes and Proteobacteria) isolated from the study participants. For instance, the relative abundance of family Bacillaceae from malignant (26\%) was lower than the normal biopsies (39\%). On other hand, family Enterobacteriaceae was twice more abundant in malignant tissues (45\%) than in its matched normal tissues (23\%). Furthermore, the family Enterococcaceae (14\%) of phylum Firmicutes was solely isolated from malignant tissue biopsies.
\end{abstract}

\footnotetext{
*Correspondence: yesufadems@yahoo.com

${ }^{1}$ Department of Medical Laboratory Sciences, School of Health Sciences,

College of Medicine and Health Sciences, Bahir Dar University, P.O. Box 79, Bahir Dar, Ethiopia

Full list of author information is available at the end of the article
}

c) The Author(s) 2021. This article is licensed under a Creative Commons Attribution 4.0 International License, which permits use, sharing, adaptation, distribution and reproduction in any medium or format, as long as you give appropriate credit to the original author(s) and the source, provide a link to the Creative Commons licence, and indicate if changes were made. The images or other third party material in this article are included in the article's Creative Commons licence, unless indicated otherwise in a credit line to the material. If material is not included in the article's Creative Commons licence and your intended use is not permitted by statutory regulation or exceeds the permitted use, you will need to obtain permission directly from the copyright holder. To view a copy of this licence, visit http://creativeco mmons.org/licenses/by/4.0/. The Creative Commons Public Domain Dedication waiver (http://creativecommons.org/publicdomain/ zero/1.0/) applies to the data made available in this article, unless otherwise stated in a credit line to the data. 
Conclusions: The overall microbial composition of normal and malignant tissues was considerably different among the study participants. Further culture independent analysis of mucosal microbiota will provide detail pictures of microbial composition differences and pathogenesis of CRC in Ethiopian settings.

Keywords: Gut microbiota, Culture-based, Mucosal biopsies, Colorectal cancer, Ethiopia

\section{Background}

Colorectal cancer (CRC) is the fourth most common causes of cancer deaths in the world with about 900,000 deaths annually [1] next to lung cancer [2]. It accounts for approximately $10 \%$ of cancer-related mortality in western countries [3]. Although a population based data is unavailable from Ethiopia, colorectal cancer is a major problem with significant magnitude of unresectable tumors [4]. Based on a single cancer registry data of Addis Ababa City, the Global cancer statistics center reported 4716 (7\%) new CRC cases in 2018 [2] which makes CRC ranked at the third of cancer cases in Ethiopia.

Various non-modifiable and environmental factors are casually associated with the incidence of colorectal cancer. Age and hereditary factors are among non-modifiable factors that cannot be controlled by an individual while environmental factors including dietary change, urban residence, smoking habit, heavy alcohol consumption, and physical inactivity and obesity are considered as modifiable factors [5].

Inflammatory bowel diseases (ulcerative colitis and Crohn's disease) are keenly associated with the development of colorectal cancer in which various immune regulatory pathways have been identified in ulcerative colitis associated CRC [5, 6]. Among these, chronic intestinal inflammation, defective mucosal barrier and hostmicrobe dynamics promote tumorigenesis of colorectal regions of gastrointestinal tract [6]. Moreover, microbialinduced chronic colitis drives the progression of adenoma to invasive carcinoma [7].

In spite of microbial composition of the human intestine is obviously correlated to the health conditions, human gut microbiota have emerged as a major environmental factor that modulate the risk of colorectal cancer. Dysbiosis of gut microbiota $[8,9]$ is now assumed to be an underlying factor in the development of colorectal cancer. Currently, several researches are trying to associate the change in the composition of human intestinal microbiota with colorectal cancer occurrence. However, most studies might not show strong association due to different constraints including use of non-intestinal biopsy investigations and convenience of specimen [10]. Mucosa-associated microbiota potentially affects CRC risk primarily through direct interaction with the host [11] and its significantly differed organization in CRC patients and healthy individuals [12].
Granting an increase in prevalence of colorectal cancer has been documented from developing countries [2, 13], reports on gut microbiota in relation to colorectal cancer are not yet issued particularly in Ethiopia. Phenotypic, genotypic and toxin gene analyses of gut microbiota composition have not yet been done among colorectal cancer patients in the study area and in Ethiopia at large. Therefore, this study is aimed at determining the microbial distribution and characterizing cultivable aerobic gut mucosal associated bacteriobiota among cancerous and adjacent apparently normal tissues of colorectal cancer patients.

\section{Result}

Fifteen colorectal cancer patients were recruited from two referral hospitals: Felege Hiwot Referral Hospital $(\mathrm{n}=8)$ and University of Gondar Teaching Hospital $(n=7)$. Nine $(60 \%)$ were males with a male to female ratio of 1.5:1. The cumulative mean age \pm SD of the study participants were $53.8 \pm 10.8$ years with a range of 38 and 79 years old. Eleven $(73.3 \%)$ of the study participants were between the age groups of 38 and 60 years of the first two quartiles while elders with $\geq 60$ years old were only $4(26.7 \%)$ (Table 1$)$.

The overall abundance of cultivable aerobic bacteria was recovered from triplicate culture plates and compared with types of biopsies. The mean \pm SD population of aerobic bacteria cultivated from normal-featuring biopsies was approximately $4.0 \times 10^{5} \pm 2.2 \times 10^{5} \mathrm{CFU} /$

Table 1 Socio-demographic characteristics of study participants with colorectal cancer

\begin{tabular}{lllll}
\hline & 1st Quartile & 2nd Quartile & 3rd Quartile & Total \\
& $N(\%)$ & $N(\%)$ & $N(\%)$ & $N(\%)$ \\
& $4(26.7)$ & $7(46.6)$ & $4(26.7)$ & $15(100)$ \\
\hline Age (in years) & & & & \\
Mean \pm SD & $40.8 \pm 3.6$ & $54.6 \pm 4.7$ & $65.5 \pm 9.1$ & $53.8 \pm 10.8$ \\
Median & 39.5 & 56 & 61.5 & 56 \\
Minimum & 38 & 48 & 60 & 38 \\
Maximum & 46 & 59 & 79 & 79 \\
Sex & & & & \\
Male N (\%) & $3(75)$ & $4(57)$ & $2(50)$ & $9(60)$ \\
Female N (\%) & $1(25)$ & $3(43)$ & $2(50)$ & $6(40)$ \\
Male:female ratio & $1.5: 1$ & & & \\
\hline
\end{tabular}




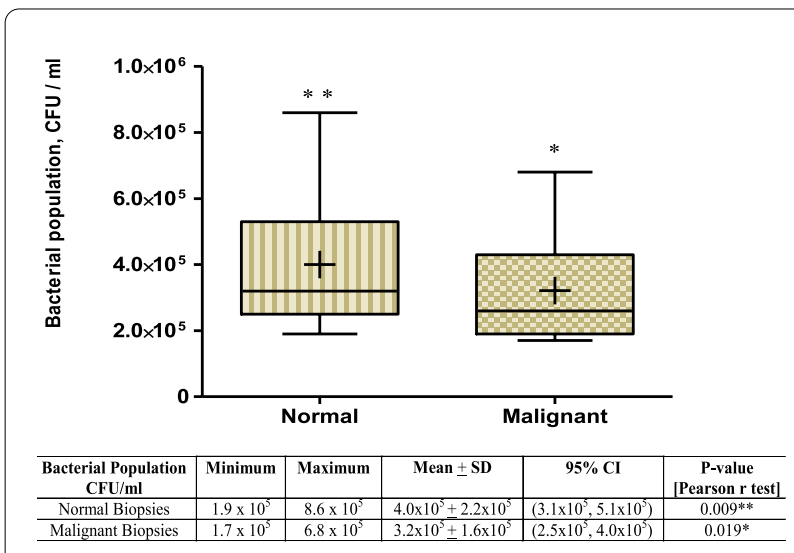

Fig. 1 Box-Whisker plot of bacterial microbiota abundance in normal and malignant tissue biopsies of CRC patients. The plot shows median values, means (+ sign in boxes), interquartile ranges (IQR) (boxes) and $1.5 \times$ IQR (whiskers). Bacterial population isolated from paired biopsies of CRC patients was significantly associated with the occurrence of tumor at $\left({ }^{*} \mathrm{p}<0.05\right)$ or being normal tissue at $\left({ }^{* *} \mathrm{p}<0.01\right)$

$\mathrm{ml}$ while it was $3.2 \times 10^{5} \pm 1.6 \times 10^{5} \mathrm{CFU} / \mathrm{ml}$ from malignant tissues. According to the Pearson $r$ test, significant correlation was observed between a reduced bacterial microbiota (dysbacteriosis) of washed malignant tissue suspensions and the occurrence of colorectal cancer $(\mathrm{p}=0.019$, Pearson $\mathrm{r}=0.596,95 \% \mathrm{CI}=0.120-0.849)$ (Fig. 1).

As the Box-Whiskers appearance indicates, the mean bacterial population of malignant was significantly different from the adjacent normal tissues biopsies at $\mathrm{p}<0.05$ (Fig. 1). The relative abundance of bacteria at family or genus level in each cancerous specimen was much smaller compared to the other equivalent normal tissue biopsies. The upper range value of bacterial abundance of malignant tissues $\left[6.8 \times 10^{5} \mathrm{CFU} / \mathrm{ml}\right]$ was reduced at a minimum of $2.0 \times 10^{5} \mathrm{CFU} / \mathrm{ml}$ of washed biopsy suspension from its matched normal tissue biopsies count $\left[8.6 \times 10^{5} \mathrm{CFU} / \mathrm{ml}\right]$. Similarly, the lower range value of washed malignant tissue biopsies $\left[1.7 \times 10^{5} \mathrm{CFU} / \mathrm{ml}\right]$ was also $2.0 \times 10^{4} \mathrm{CFU} / \mathrm{ml}$ fewer than its equivalent counts of adjacent normal tissues $\left[1.9 \times 10^{5} \mathrm{CFU} / \mathrm{ml}\right]$ (Fig. 1).

Comparing the mucosal microbiota of malignant niche to its matched adjacent normal tissues indicated varied bacterial compositions over those two groups of samples of CRC patients. Three bacterial phyla; Proteobacteria $(55.6 \%)$, Firmicutes $(33.3 \%)$ and Fusobacteria $(11.1 \%)$ were over represented in non-malignant tissues of CRC patients (Fig. 2) while only two phyla; Firmicutes (41.2\%) and Proteobacteria (58.8\%) were recovered from malignant biopsies of CRC patients (Fig. 3). In addition, more bacterial diversity has been observed from apparently healthy tissue specimens group than its equivalent

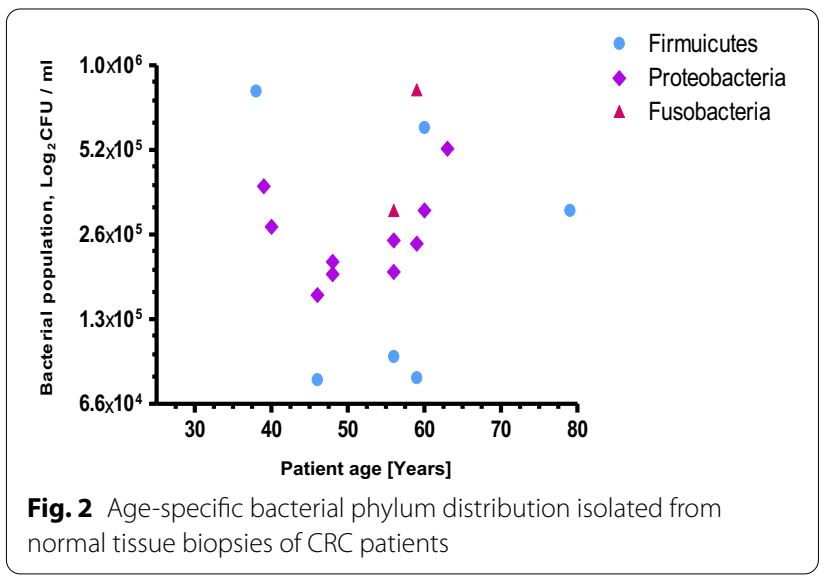

particularly among the age groups of 55 to 65 years (Figs. 2, 3).

Though most members of phylum Fusobacteria are obligate anaerobic bacteria, a genus Streptobacillus (Fig. 4) under a family Leptotrichiaceae $(20 \%)$ with a microaerophilic nature was recovered only from the normal tissue biopsies using $\mathrm{CO}_{2}$ enriched cultivation. Phyla Firmicutes and Proteobacteria recovered from both groups of tissues showed no difference while family level differences between biopsy groups were observed. The relative abundance of family Bacillaceae isolated from non-malignant tissue biopsies was at (39\%) of the total isolated bacterial families while it was much lower proportion (26\%) from malignant tissue biopsies. On the other hand, the relative abundance of family Enterobacteriaceae $(45 \%)$ isolated from malignant tissue was twice higher than from the matched control biopsies (23\%). Furthermore, the family Enterococcaceae (14\%) was isolated only from malignant biopsies of CRC patients (Fig. 4).

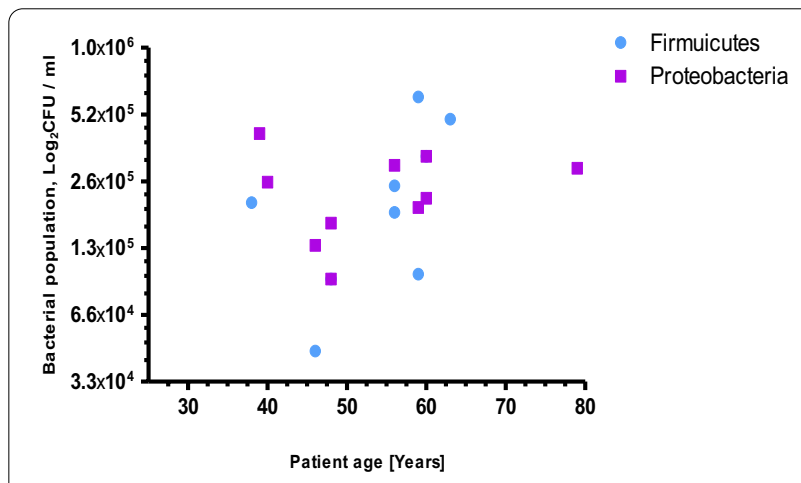

Fig. 3 Age-specific bacterial phylum distribution isolated from malignant tissue of biopsies of CRC patients 

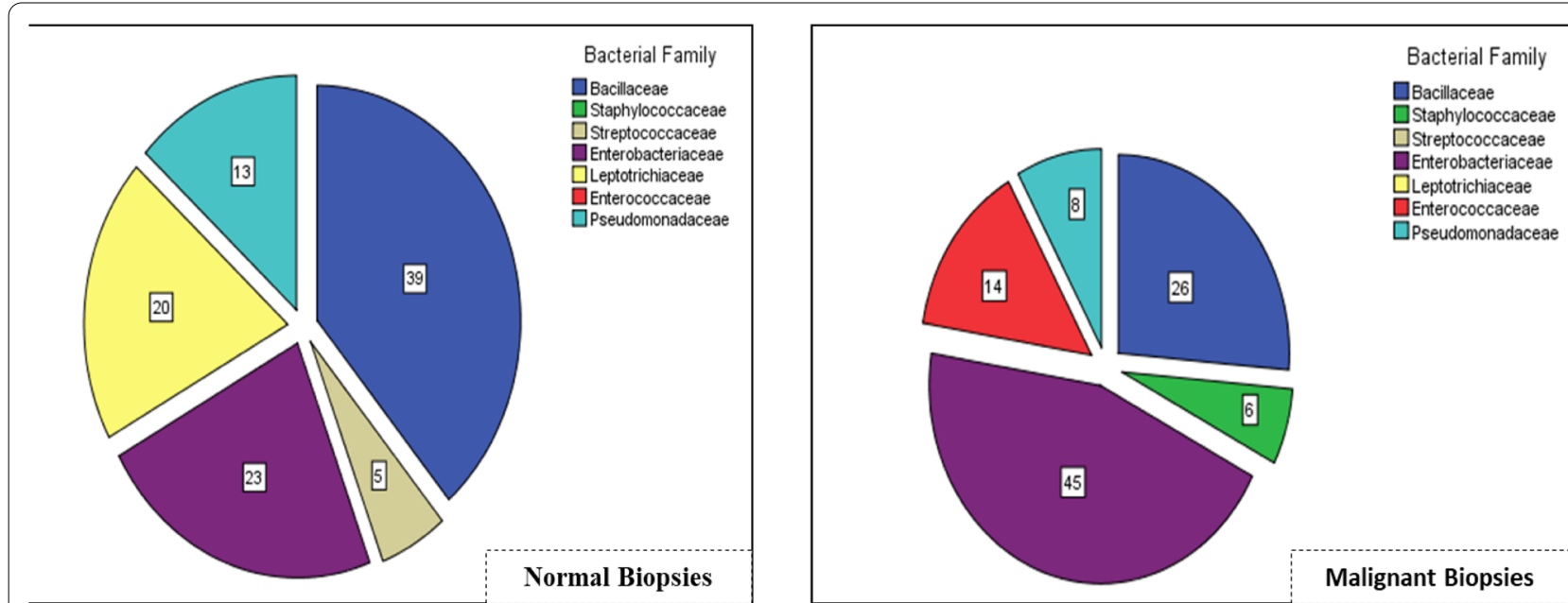

Fig. 4 Bacterial family distribution in Normal and Malignant biopsies of CRC patients. Numbers are in percentage of the total family coverage

\section{Discussion}

The variability of microbial population of gastrointestinal tract is currently correlated to the occurrence of different disorders including colorectal cancer. Though several recent advanced researches in developed countries use genomic and metagenomic approaches to characterize microbial cells in feacal or mucosal specimens, there is no any published data related to the overall microbiota profile of mucosal or feacal specimens of CRC patients in Ethiopia. Therefore, the current study was aimed at determining the distribution of at least cultivable aerobic bacterial microbiota of cancerous and normal-featuring tissues of CRC patients.

The dysbiosis of bacterial microbiota abundance and distribution in malignant tissues from adjacent normal biopsies is currently become an indicative in the diagnosis and prognosis of CRC patients. These alterations are also demonstrated in our study by the presence of abundant bacterial microbiota in normal biopsies $\left[\bar{x}=4.0 \times 10^{5}\right.$ $\mathrm{CFU} / \mathrm{ml}$ ] while much smaller bacterial population [approximately $2.0 \times 10^{5} \mathrm{CFU} / \mathrm{ml}$ less] from malignant tissue biopsies of CRC patients (Fig. 1).

In this study, we found higher abundance of bacterial composition of phyla; Proteobacteria (55.6\%), Firmicutes (33.3\%) and Fusobacteria (11.1\%) in normal biopsies of CRC patients (Fig. 2). However, it is much different from a study reported by Eckburg et al. [14], in which $90 \%$ of bacterial composition of normal luminal microbiota belongs to the phyla; Firmicutes and Bacteriodes, the remaining minor constituents were Proteobacteria and Actinobacteria. On the other hand, a review study by Villeger et al. [15] presented a clear increase in both Proteobacteria and Bacteroidetes in tissues from patients with colorectal adenoma compared with tissues from healthy volunteers. Among members of phylum Fusobacteria [16], only a genus Streptobacillus in the family Leptotrichiaceae was isolated from normal tissues of CRC patients (Fig. 2). It could be due to the alternative method we employed, candle jar for fastidious bacterial cultivation, probably supported the growth of microaerophilic bacteria. Other most fusobacterial members strictly require anaerobic environment to grow [17] and are associated greatly with cancer tissues than in normal tissues [18]. Despite the genera Bacteriodes [19], Leptotrichia species $[20,21]$ and Fusobacteria $[19,22]$ were the most frequently identified and reported bacteria from malignant tissues of colorectal cancer, our study didn't showed any above mentioned species while we employed candle jar cultivation.

According to the author Lau et al. [23], Streptobacillus hongkongensis is a novel bacterial species that permanently found in human oropharynx and there might be more other Streptobacillus species probably also residing in human oropharynx. This genus might get easy access to the lumen of the colorectal regions [24].

The microbial abundance of family Bacillaceae in malignant biopsies $(26 \%)$ was lower than the abundance in non-malignant tissues (39\%) while the family Enterobacteriaceae, a member of phylum Proteobacteria [25] was over-represented (45\%) from malignant group of tissue (Fig. 4). This observation could be supported by the fact that family Enterobacteriaceae is considerably a member of the carcinogenic bacteria that constitute Lipopolysaccharides (LPS), D-Lactate and other bacterial components which positively correlated with the incidence and progression of inflammatory bowel diseases (IBD) as well as colorectal cancer [26-28]. 
More recently, studies [15, 29] indicated a drastic difference in the microbial composition has been observed in the mucosa of colitis-associated CRC patients, with an increase in the family Enterobacteriaceae compared with the mucosa of sporadic CRC patients. For instance, colibactin-producing $E$. coli were more frequently identified in microsatellite stable CRC and higher colonization by negative-colibactin $E$. coli bacteria were detected in patients with microsatellite instability CRC [15].

Our study also revealed that significant abundance of family Enterococcaceae was identified only from malignant biopsies (Fig. 4). This finding supports previously reported evidences that patients with ulcerative colitis and Crohn's disease have larger members of family Enterococcaceae than healthy controls [30-32]. Furthermore, genus Enterococcus is among certain bacterial species that has been identified to play a key role in the incidence and development of colorectal cancer [15, 29]. In this genus, Enterococcus faecalis can even trigger macrophages and other immune cells to produce procarcinogenic enzymes capable of damaging target cell DNA that contribute to CRC carcinogenesis [33, 34].

The imbalance of these bacteria and their gene products $[35,36]$ that underlies mucosal surface of intestinal microvilli would facilitate the replication of opportunistic pathogens which might have direct contribution in the onset and progression of severe gastrointestinal inflammation leading to colorectal cancer. Hence, these findings could be a base of future investigations focusing on potential pro-oncogenic pathogens of gastrointestinal cancers in the study area.

\section{Strengths}

The current study used intact biopsies of both malignant and adjacent normal appearing tissues of study participants where most faecal specimen microbiome studies might not show typical characteristics of adherent gut microbiota of the colorectal cancer patients.

\section{Limitations}

Colonoscopy is an invasive procedure to get intestinal tissue biopsies from healthy individuals; consequently we didn't include apparently healthy individuals as a control group. Furthermore, our study employed a culture-based aerobic cultivation, huge segment of mucosal-associated microbiota such as obligate anaerobes, fungal agents and uncultivable microbes were not addressed. Microbial distributions in relation to anatomic positions of colorectal biopsies, cancer stage, anticancer or antibiotic use, comorbid diseases and long term dietary habit were not considered. However, with these limitations, the study will provide base line information for future development of culture independent studies of gut microbiota in the study area.

\section{Conclusions}

Findings presented in the current study suggested a relative abundance and distributions of cultivable aerobic bacterial microbiota of malignant tissues were significantly different from its adjacent normal tissue biopsies. Our study also showed that families of Enterobacteriaceae and Enterococcaceae were the most frequently recovered bacterial family from malignant tissues while detail considerations of these bacteria in the initiation and progression of colorectal cancer remains unclear. Therefore, large scale and deep metagenomic analysis of gut microbiota differences in Ethiopian population play key roles in the future development of advanced diagnostic, prognostic and therapeutic strategies of colorectal cancer patients.

\section{Methods}

\section{Patient recruitment and mucosal biopsy}

At Gasteroenterology and Digestive Clinics of Felege Hiwot Referral and University of Gondar Teaching Hospitals, 15 confirmed CRC patients who underwent surgical resections of cancerous tissues were enrolled in the study during the study period of April, 2017 to February, 2018. Patients who were confirmed solely for colorectal cancer and appointed for open colorectal surgery were included in the study. These patients were instructed for bowel preparation before surgery carried out. However, patients who had been administered with antibiotics in the last two weeks prior to surgery, who exhibited either metastases or other cancers (liver, pancreatic and lung cancers) and who presented insufficient tissue biopsies were excluded from the study. Informed consent from each study participant was obtained and information was kept confidential. Two biopsies (with 5-7 ×5-7 mm dimensions) were collected from malignant and adjacent normal-appearing tissues of the colorectal lumen of CRC patients during open resection surgery. Each biopsy specimen was aseptically collected using sterile falcon tube containing sterile normal saline and immediately processed in the bacteriology laboratory. Saline washed biopsy suspensions were used for aerobic cultivation. Biopsy specimens were preserved at $4{ }^{\circ} \mathrm{C}$ where delayed analysis was unavoidable. Findings were analyzed and interpreted accordingly using statistical software.

\section{Bacterial count and identification}

All collected biopsies were intensively washed with $5 \mathrm{ml}$ of normal saline. Twenty $\mu \mathrm{l}$ suspension of each saline-washed specimen was suspended on to each three plates of meat peptone agar. MacConkey agar, a 
selective media, was also employed to isolate common pathogenic bacteria like Salmonella and Shigella species. Colony forming unit (CFU) count, morphological characteristics of bacterial isolates at average logarithmic growth phase and identification of bacterial species using a series of biochemical tests were aseptically performed. Sterility and performance of the prepared media were checked by parallel inoculation of locally available control strains of American Type Culture Collection: S. aureus $\left(\right.$ ATCC $\left.^{\circledR}-25,923\right)$, P. aeruginosa (ATCC $\left.^{\circledR}-27,853\right)$ and $E$. coli $\left(\mathrm{ATCC}^{\circledR}-25,922\right)$.

\section{Statistical analysis}

Before we performed statistical analysis, the data were transformed into a natural logarithm $(\ln )$ of bacterial populations of malignant and adjacent normal tissues. Hence, positive skewness of our data was changed from 1.386 to 0.810 with acceptable normal distribution (Additional file 1: S1 Figure, S2 Figure). Statistical data analysis and plotting were performed using Microsoft excel 2010, GraphPad Prism5 or SPSS version 20 software accordingly. Pearson $r$ test, mean and standard deviation were employed. Statistically significant level was considered at $\mathrm{p} \leq 0.05$.

\section{Abbreviations}

CAC: Colitis-associated cancer; CFU: Colony forming unit; CRC: Colorectal cancer; IBD: Inflammatory bowel disease; IQR: Interquartile range; IRB: Institutional Review Board.

\section{Supplementary Information}

The online version contains supplementary material available at https://doi. org/10.1186/s13099-021-00415-7.

Additional file 1: Figure S1. Normal distribution of bacterial population isolated from adjacent normal biopsies of colorectal cancer patients. Original bacterial population data were transformed using a natural logarithm function (In) and Pearson $r$ correlation test was performed using transformed data. Figure $\mathbf{S 2}$. Normal distribution of bacterial population isolated from malignant biopsies of colorectal cancer patients. Original bacterial population data were transformed using a natural logarithm function (In) and Pearson r correlation test was performed using transformed data.

\section{Acknowledgements}

We would like to express our deepest gratitude to Felege Hiwot Referral Hospital Laboratory staffs for their generous support during laboratory investigations. Our appreciation goes to Felege Hiwot Referral Hospital and Amahara Public Health Institute for their kind provision of available control ATCC strains. The authors would like to thank Mr. Zelalem Mehari for his support in statistical analysis and Dr. Dawit Amogne for his editorial assistance.

\section{Authors' contributions}

YA contributed to study conception and design, laboratory investigations, acquisition of data, data analysis and interpretation and wrote the first draft and final version of manuscript; $\mathrm{MG}$ and $\mathrm{MO}$ contributed to study participant enrolment, demonstrated the quality of biopsies, final manuscript preparation.
YZ contributed to study conception and design, laboratory investigations, acquisition of data, final manuscript preparation. All authors read and approved the final manuscript.

\section{Funding}

This research was funded by Bahir Dar University, College of Medicine and Health Sciences-Staff Research Grant/2016-17.

\section{Availability of data and materials}

The datasets collected and analyzed in the present study are available with the first author up on request.

\section{Declarations}

\section{Ethics approval and consent to participate}

Any study participant who was not willing to participate in the study was not forced to participate. Data obtained from the study participants were kept confidential using only codes.

\section{Competing interests}

We authors declare that we have no competing interest.

\section{Author details}

${ }^{1}$ Department of Medical Laboratory Sciences, School of Health Sciences, College of Medicine and Health Sciences, Bahir Dar University, P.O. Box 79, Bahir Dar, Ethiopia. ${ }^{2}$ Department of General Surgery, School of Medicine, College of Medicine and Health Sciences, Bahir Dar University, P.O. Box 79, Bahir Dar, Ethiopia. ${ }^{3}$ Department of Surgery, School of Medicine, College of Medicine and Health Sciences, University of Gondar, P.O.Box 196, Gondar, Ethiopia. ${ }^{4}$ CDT-Africa, College of Health Sciences, Addis Ababa University, P.O. Box 9086, Addis Ababa, Ethiopia. ${ }^{5}$ Biotechnology Research Institute, Bahir Dar University, P.O. Box 79, Bahir Dar, Ethiopia.

Received: 3 June 2020 Accepted: 15 March 2021

Published online: 22 March 2021

\section{References}

1. Dekker E, Tanis PJ, Vleugels JLA, Kasi PM, Wallace MB. Colorectal cancer. Lancet. 2019;394:1467-80. https://doi.org/10.1016/S0140-6736(19) 32319-0.

2. Bray F, Ferlay J, Soerjomataram I, Siegel RL, Torre LA, Jemal A. Global cancer statistics 2018: GLOBOCAN estimates of incidence and mortality worldwide for 36 cancers in 185 countries. CA Cancer J Clin. 2018;68(6):394-424. https://doi.org/10.3322/caac.21492.

3. Kuipers EJ, Grady WM, Lieberman D, Seufferlein T, Sung JJ, Boelens PG, et al. Colorectal cancer. Nat Rev Dis Prim. 2015. https://doi.org/10.1038/ nrdp.2015.65.

4. Zemenfes D, Kotisso B. A two-year review of colorectal cancer at Tikur Anbessa Specialized Hospital, Addis Ababa, Ethiopia. East Cent African J Surg. 2015;20(2):10-6.

5. Haggar FA, Boushey RP. Colorectal cancer epidemiology: incidence, mortality, survival, and risk factors. Clin Colon Rectal Surg. 2009;22(4):191-7. https:/doi.org/10.1055/s-0029-1242458.

6. Waldner MJ, Neurath MF. Mechanisms of immune signaling in colitisassociated cancer. Cell Mol Gastroenterol Hepatol. 2014;1 (1):6-16. https:// doi.org/10.1016/j.jcmgh.2014.11.006.

7. Uronis JM, Mühlbauer M, Herfarth HH, Rubinas TC, Jones GS, Jobin C. Modulation of the intestinal microbiota alters colitis-associated colorectal cancer susceptibility. PLoS One. 2009:4(6):e6026. https://doi.org/10.1371/ journal.pone.0006026.

8. Thursby E, Juge N. Introduction to the human gut microbiota. Biochem J. 2017:474:1823-36. https://doi.org/10.1042/BCJ20160510.

9. $\mathrm{Ni} \mathrm{J,} \mathrm{Wu} \mathrm{GD,} \mathrm{Albenberg} \mathrm{L,} \mathrm{Tomov} \mathrm{VT.} \mathrm{Gut} \mathrm{microbiota} \mathrm{and} \mathrm{IBD:} \mathrm{causation} \mathrm{or}$ correlation? Nat Rev Gastroenterol Hepatol. 2017;14:573-84. https://doi. org/10.1038/nrgastro.2017.88.

10. Pagnini $C$, Delle Fave G. Letter: investigating the intestinal mucosa-associated microbiota-relevance and potential pitfalls. Aliment Pharmacol Ther. 2016;44(6):647-8. https://doi.org/10.1111/apt.13686 
11. Chen W, Liu F, Ling Z, Tong X, Xiang C. Human intestinal lumen and mucosa-associated microbiota in patients with colorectal cancer. PLoS One. 2012. https://doi.org/10.1371/journal.pone.0039743.

12. Mandal RS, Saha S, Das S. Metagenomic surveys of gut microbiota. Genomics Proteomics Bioinform. 2015;13(3):148-58. https://doi.org/10. 1016/j.gpb.2015.02.005.

13. Feuchtner J, Mathewos A, Solomon A, Timotewos G, Aynalem A, Wondemagegnehu T, et al. Addis Ababa population-based pattern of cancer therapy, Ethiopia. PLoS One. 2019;14(9):e0219519. https://doi.org/10. 1371/journal.pone.0219519.

14. Eckburg PB, Bik EM, Bernstein CN, Purdom E, Dethlefsen L, Sargent $\mathrm{M}$, et al. Diversity of the human intestinal microbial flora. Science. 2005;308(5728):1635-8. https://doi.org/10.1126/science.1110591.

15. Villéger R, Lopès A, Veziant J, Gagnière J, Barnich N, Billard E, et al. Microbial markers in colorectal cancer detection and/or prognosis. World J Gastroenterol. 2018;24(22):2327-412. https://doi.org/10.3748/wjg.v24.i22. 2327

16. Bergey DH. Bergey's manual of systematic bacteriology. Bacteroidetes, vol. 4. New York: Springer; 2010. https://doi.org/10.1007/ 978-0-387-68572-4

17. Kasper SH, Morell-Perez C, Wyche TP, Sana TR, Lieberman LA, Hett EC. Colorectal cancer-associated anaerobic bacteria proliferate in tumor spheroids and alter the microenvironment. Sci Rep. 2020;10(1):5321. https://doi.org/10.1038/s41598-020-62139-z

18. Jahani-Sherafat S, Alebouyeh M, Moghim S, Amoli HA, Ghasemian-Safaei $H$. Role of gut microbiota in the pathogenesis of colorectal cancer; a review article. Gastroenterol Hepatol Bed Bench. 2018;11(2):101-9.

19. Edmiston CE, Avant GR, Wilson FA. Anaerobic bacterial populations on normal and diseased human biopsy tissue obtained at colonoscopy. Appl Environ Microbiol. 1982;43(5):1173-81. https://doi.org/10.1128/AEM.43.5. 1173-1181.1982.

20. Castellarin M, Warren RL, Freeman JD, Dreolini L, Krzywinski M, Strauss J, et al. Fusobacterium nucleatum infection is prevalent in human colorectal carcinoma. Genome Res. 2012;22(2):299-306. https://doi.org/10.1101/gr. 126516.111

21. Kostic AD, Gevers D, Pedamallu CS, Michaud M, Duke F, Earl AM, et al. Genomic analysis identifies association of Fusobacterium with colorectal carcinoma. Genome Res. 2012;22(2):292-8. https://doi.org/10.1101/gr. 126573.111.

22. Warren RL, Freeman DJ, Pleasance S, Watson P, Moore RA, Cochrane K, et al. Co-occurrence of anaerobic bacteria in colorectal carcinomas. Microbiome. 2013;1(1):16. https://doi.org/10.1186/2049-2618-1-16.

23. Lau SKP, Chan JFW, Tsang CC, Chan SM, Ho ML, Que TL, et al. Human oropharynx as natural reservoir of Streptobacillus hongkongensis. Sci Rep. 2016;6:24419. https://doi.org/10.1038/srep24419.

24. Zhao L, Zhang X, Zuo T, Yu J. The composition of colonic commensal bacteria according to anatomical localization in colorectal cancer. Engineering. 2017;3(1):90-7. https://doi.org/10.1016/J.ENG.2017.01.012.

25. Bergey, William DH, Whitman B, Goodfellow M, Kämpfer P, Hans-Jürgen. Bergey's manual ${ }^{\circledR}$ of systematic bacteriology. In: The Proteobacteria, vol. 2, New York: Springer; 2005. https://doi.org/10.1007/0-387-28022-7
26. Liu X, Cheng Y, Shao L, Ling Z, Huang Y. Alterations of the predominant fecal microbiota and disruption of the gut mucosal barrier in patients with early-stage colorectal cancer. Biomed Res Int. 2020;2020:2948282. https://doi.org/10.1155/2020/2948282.

27. Altomare A, Putignani L, Del Chierico F, Cocca S, Angeletti S, Ciccozzi M, et al. Gut mucosal-associated microbiota better discloses inflammatory bowel disease differential patterns than faecal microbiota. Dig Liver Dis. 2019;51(5):648-56. https://doi.org/10.1016/j.dld.2018.11.021.

28. Tlaskalová-Hogenová H, Štěpánková R, Hudcovic T, Tučková L, Cukrowska B, Lodinová-Žádníková R, et al. Commensal bacteria (normal microflora), mucosal immunity and chronic inflammatory and autoimmune diseases. Immunol Lett. 2004;93(23):97-108. https://doi.org/10.1016/j.imlet.2004. 02.005 .

29. Liu CJ, Zhang YL, Shang YUN, Wu B, Yang EN, Luo YY, et al. Intestinal bacteria detected in cancer and adjacent tissue from patients with colorectal cancer. Oncol Lett. 2019;17(1):1115-27. https://doi.org/10.3892/ol.2018. 9714.

30. Růžičková M, Vítězová M, Kushkevych I. The characterization of Enterococcus genus: resistance mechanisms and inflammatory bowel disease. Open Med. 2020;15:211-24. https://doi.org/10.1515/med-2020-0032.

31. Zhou Y, Chen H, He H, Du Y, Hu J, Li Y, et al. Increased Enterococcus faecalis infection is associated with clinically active Crohn disease. Medicine. 2016;95(39):e5019. https://doi.org/10.1097/MD.0000000000005019.

32. Van Der Wiel Korstanje JA, Winkler KC. The faecal flora in ulcerative colitis. J Med Microbiol. 1975;8(4):491-501. https://doi.org/10.1099/00222 615-8-4-491.

33. Xingmin Wang TD, Allen. Yonghong Yang DRM and MMH. Cyclooxygenase-2 Generates the Endogenous Mutagen trans-4- Hydroxy-2-nonenal in Enterococcus faecalis-infected Macrophages. Cancer Prev Res. 2014;6(3):206-216. https://doi.org/10.1158/1940-6207.CAPR-12-0350

34. Wang X, Allen TD, May RJ, Lightfoot S, Houchen CW, Huycke MM. Enterococcus faecalis induces aneuploidy and tetraploidy in colonic epithelial cells through a bystander effect. Cancer Res. 2008;68(23):9909_ 18. https://doi.org/10.1158/0008-5472.CAN-08-1551

35. Graessler J, Qin Y, Zhong H, Zhang J, Licinio J, Wong ML, et al. Metagenomic sequencing of the human gut microbiome before and after bariatric surgery in obese patients with type 2 diabetes: Correlation with inflammatory and metabolic parameters. Pharmacogenomics J. 2013;13:514-22.

36. Dhakan DB, Maji A, Sharma AK, Saxena R, Pulikkan J, Grace T, et al. The unique composition of Indian gut microbiome, gene catalogue, and associated fecal metabolome deciphered using multi-omics approaches. Gigascience. 2019;8(3):giz004. https://doi.org/10.1093/gigascience/ giz004.

\section{Publisher's note}

Springer Nature remains neutral with regard to jurisdictional claims in published maps and institutional affiliations.

Ready to submit your research? Choose BMC and benefit from

- fast, convenient online submission

- thorough peer review by experienced researchers in your field

- rapid publication on acceptance

- support for research data, including large and complex data types

- gold Open Access which fosters wider collaboration and increased citations

- maximum visibility for your research: over 100M website views per year

At BMC, research is always in progress.

Learn more biomedcentral.com/submissions 